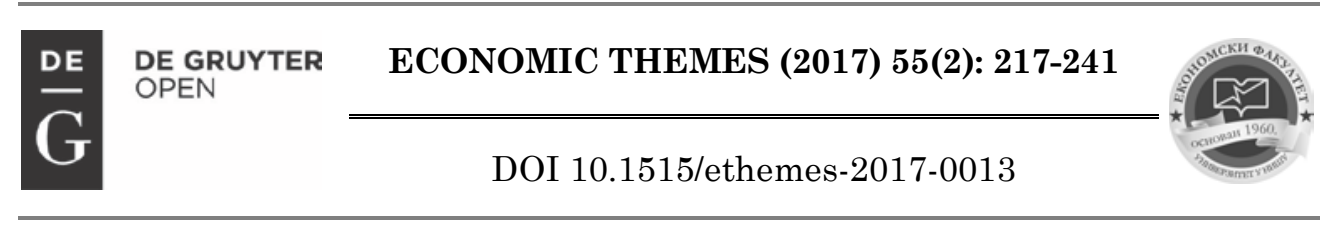

\title{
COMPARATIVE ANALYSIS OF SERBIAN AND EUROPEAN LEGISLATION IN THE AREA OF WASTE MANAGEMENT
}

\author{
Mladen Krstić
}

University of Nis, Faculty of Economics, Republic of Serbia

$\bowtie$ mlkrsta@gmail.com

\section{Tamara Milenković-Kerković}

University of Nis, Faculty of Economics, Republic of Serbia

$\triangle$ tamara.kerkovic@eknfak.ni.ac.rs

UDC

005.936.5:3

46.91(4-

672EU:497.

11)

Review

paper
Received: 29.11.2016. Accepted: 15.05.2017.
Abstract: Waste management, ecological consciousness and environmental protection have become increasingly topical issues ever since the beginning of the $21^{\text {st }}$ century, and in favour of this claim is the fact that there is an increasing number of authors dealing with environmental law, as well the level of global ecological consciousness. The contemporary consumer society is characterized by the fact that it creates a plethora of different kinds of waste. The goal is to create a modern system of integrated waste management in order to encompass the cycle of manufacturing and consumption with a recycling process at the end of the consumer products lifespan. The purpose of this paper is to provide an overview of the European legislation, as well as to analyse the Serbian legislation in the area of waste management. The European legislation on waste management is much older and far more developed than its Serbian counterpart, hence, it represents the foundation for future development of regulations in Serbia. The current waste management legislation in Serbia is largely based on the EU legislation, however, owing to the insufficiently matured and stable Serbian institutions, implementation of these regulations is below the expected level.

Keywords Environmental policy, waste management, recycling, legislation, waste reporting system.

JEL classification: K32, Q56

\section{Introduction}

The expansion of manufacturing, shortening of the lifespan of consumer products, and an increasingly fast-paced lifestyle dynamic greatly influenced the creation of large quantities of waste. The enormous pressure on natural resources, as well as 
the greater need for a healthy environment stressed even further the issue of waste creation, storage, and its adequate treatment.

Formulating the National Sustainable Development Strategy, and, along with it, adequate strategies of waste management appear to be the only viable solution to the problem. It is necessary to pass adequate laws and bylaws, as well as to develop institutions that would deal with their implementation. As a part of its European Union (EU) accession process, Serbia is obliged to implement a great deal of EU member states' legislation related to waste management. There are several reasons why waste management is an exceptionally arduous issue in Serbia. Namely, owing to the low standard of living, in recent times, Serbia has become the final destination for products that are either almost completely worn out, or their lifespan is nearly finished. Developed countries are not willing to invest in the recycling process, owing to the fact that it requires considerable funds, therefore, it is more economically sound to export these products into less developed countries, thus solving the potential recycling issue. Over a period of time, starting with used automobiles, used household appliances, and other kinds of devices, Serbia has accumulated a considerable base of raw materials for the development of the recycling industry. On the other hand, there is a daily creation of municipal waste, as well as industrial waste that also require inclusion into adequate protocols for storage and treatment. Waste represents a form of energy source, and, therefore, an inadequate treatment of waste leads to considerable loss for the society as a whole.

This paper will firstly deal with the origin and development of environmental law in the EU, pointing to the way environmental protection polices, ecological consciousness, and adequate legislation evolved alongside the evolution of the Union and the increase of its member states. An essential part of environmental law deals with waste management, hence, the aim of this paper will be to define waste, bearing in mind the different perspectives, as well as its distinct categorisation. There will be an overview of EU polices in relation to waste management, set objectives, standards and principles that are being promoted in the context of recycling and environmental protection. The legislation in Serbia will be addressed separately and a conclusion will be reached about the degree of compatibility between the Serbian national and European legislation.

The final part of this paper will be devoted to the implementation of legislation that business entities in Serbia are dealing with. The obligations of business entities in terms of following regulations, the creation of adequate documentation, as well as generating reports on waste transport, treatment, and storage will be particularly pointed out. Certain difficulties related to the implementation of the regulations in this area, as well as the benefits that are brought by following regulations will also be indicated.

The available literature in this area is mostly based around legislation and current regulations that additionally govern the area of waste management. The 
European legislation offers a vast array of regulations in the form of distinguished Directives, using which this complex area is regulated. The theoretical basis of legislation has had its evolutionary development, hence, it will be the subject of discussion in this paper.

Ever since the beginning of the 21st century, waste management has become an increasingly topical issue. The process of adopting Directives related to this area has intensified ever since the year 2000. Following the positive experiences of the member states, Serbia, along with other countries that are in the EU accession process, gradually adopted its national legislation to the European standards. Even though this process started later, it is led by the positive experiences of other countries, therefore, it is possible to use all its benefits, because today, as it is generally familiar, along with the economic conditions for the EU expansion, there is a lot of discussion about the environmental criteria that the future member states are required to meet. In 2010, Serbia passed the National Waste Management Strategy, thus, along with the discussion on the Law of Environmental Protection and the Law on Waste Management, in the final part of this paper there will be a discussion about legislation in Serbia, as well as its practical application. Owing to the vast complexity of the EU legislation in the area of waste management, comparing it directly to the Serbian legislation that is in an infant stage, appears to be irrational. Therefore, the European directives will be presented trough an overview, in order to demonstrate their complexity, whereas the main focus of discussion will be the current legislation in Serbia.

\section{The Development of Environmental Policy and Environmental Law}

From a historical perspective, environmental protection has not always existed as a concept in the EU organisation. Namely, the 1957 Treaty of Rome, whose ratification lead to the establishment of the European Economic Community (EEC) in its original form, did not define the environment as a separate issue. The strengthening of global ecological movements, as well as the United Nations Conference on the Human Environment, held in Stockholm in 1972, ensured that, from then onward, ecological principles were implemented in the official EEC polices, thus making environmental law an essential part of international law (Pajvančić, 2008, p. 4). Speaking in favour of this issue is the fact that the UN founded a separate agency called the United Nations Environment Programme, UNEP, in 1972 (Lilić \& Drenovak-Ivanović, 2010). Up until that moment, the priority in the Community had been assigned exclusively to trade and economic development without taking ecological principles into consideration, therefore, at the EEC summit held in Paris, there was a request from the Commission to develop an environmental protection action plan (Zdravković \& Radukić, 2006, p. 37). 
It is considered that the EU has the highest authority precisely in the domain of environmental protection where, along with dealing with the maters of internal jurisdiction, it also acts as an international subject in the international conclusions of contracts, as well as in the realisation of other means of cooperation. In this way, two distinct legal systems have been simultaneously established - at the level of the Union and at the national level of the member states. The system of the Union is autonomous in the scope of jurisdiction that has been passed on by the member states, whereas the member states are independent in the jurisdictions that they have retained. It is assumed that in this constellation of relations, there must be a high level of cooperation and aid in the implementation of regulations (Ivanjac, 1999, p. 154).

The European Union represents a unique example of cooperation and integration between the countries in the world. In the core of this process which began almost sixty years ago is economy. During the time number of areas of cooperation between the member states has been increasing, and today it is almost imposible to find social area in which coordionation among the EU members does not exist. Common care for environmental protection and creation of the area with unique standards is something that is nescessery for succesful function of common market. Environmental protection requires common work between all the countries on regional and global level respectively, where the EU is a global leader in numerous different actions (Lilić \& Drenovak-Ivanović, 2014, p. 96).

The 1992 Maastricht Treaty and the 1997 Amsterdam Treaty stand out as the tipping points in the process of implementing the legal norms related to environmental protection into the founding principles of the EU. This was the result of the fact that in the internal market there had been a growing stress on the environment, mostly owing to the increased intensity of traffic. From the aspect of ecology and the development of environmental law in the EU, these were certainly the defining moments, as subsequently, the priority from economical goals gradually shifted towards a balanced and permanent social development with a full awareness of the environment (Zdravković \& Radukić, 2006, p. 39).

Owing to the above mentioned facts, the expansion of the EU for new member states is a highly complex process. Namely, there are enormous challenges for all the candidates related to the environment, not only in terms of legislation, but also in terms of the overall environmental issues that are much bigger in the candidate countries than in the member states. In order to have the candidate countries as closer to the EU membership, there are funds that are readily available from different pre-accession funds, which are intended for funding the expensive investment projects in the area of environmental protection.

"Ever since 1973, the EEC started passing five-year action programs in the area of environmental protection, that had been initially focused primarily on removing 
or reducing the existing pollution, whereas subsequently a growing attention was devoted to taking adequate measures of prevention” (Vukasović, 2001, p. 29).

This resulted in the creation of the First Environment Action Programme in 1973. It established the foundation of environmental protection as a concept, and primarily dealt with individual activities. Continuously, from then onward, action plans have been successively passed, whereby an observation could be made that the period of validity has been increasing over the years, so that, from the initial three-year period of the First, it increased to an entire decade on the Seventh Action Programme. The increase in the planning period speaks in favour of the seriousness of its creators, not only in terms of the measures that should be taken, but also in terms of achieving the wide spectrum of objectives that have been posed by the Programmes.

Currently, the Seventh Environment Action Programme has been in effect since 2010, and will be until 2020, whereas the projection for the final realisation of its objectives is the year 2050. Therefore, this Programme defines in greater detail the short-term objectives, whereas the realisation of long-term objectives is expected much later.

The current Seventh Environment Action Programme propagates the realisation of the following objectives:

- To protect, conserve and enhance the Union's natural capital,

- To turn the Union into a resource-efficient, green and competitive lowcarbon economy,

- To safeguard the Union's citizens from environment-related pressures and risks to health and well-being,

- To maximise the benefits of Union environment legislation by improving implementation,

- To improve the knowledge and evidence base for Union environment policy,

- Environmental externalities,

- To improve environmental integration and policy coherence,

- To enhance the sustainability of the Union's cities,

- To increase the Union's effectiveness in addressing international environmental and climate-related challenges. (1386/2013/EU, article 2)

The environmental protection polices defined the basic principles and objectives that should be realised. For their realisation, it is necessary to create a complex system of legislation whose application can result in a desired implementation of the above mentioned objectives. For this reason, environmental law is one of the most regulated areas of EU legislation, primarily owing to the increasing importance of realising the objectives previously defined trough polices. 
Environmental law consists of a plethora of components, hence, owing to its complexity, we will focus exclusively on the waste management system. We will define the terms waste and systematisation of waste in greater detail, mention the most important areas that are regulated separately in the EU, and, finally, we will have an overview of the level of accomplishment in the development of the current regulations in Serbia, as well as their practical application.

\section{Types and Classifications of Waste - EU Catalogue}

The Waste Management Strategy for the Period 2010-2019 states that "Waste shall be any substance or item rejected by the owner, is intending to reject it or has to do so.” (Official Gazette of RS, no. 29/2010, p. 6) According to different criteria, there are many different categorisations of waste in literature. There are categorisations according to the origin, characteristics and contents, all according to the Law on Waste Management. (Official Gazette of RS, no. 36/2009, article 7) According to the origin, waste is divided into:

- Municipal waste (household waste),

- Commercial waste,

- Industrial waste.

According to the effects on human health and the environment, as well as the hazardous materials it might contain, waste can be divided into:

- Non-hazardous,

- Inert,

- Hazardous.

In order to have an adequate record about the daily creation of waste, it needs to be classified into groups according to adequate criteria. The Serbian Waste Catalogue includes all types of waste, including hazardous waste, and is completely in accordance with the European List of Waste/European Waste Catalogue, which is an important prerequisite in the continuation of the EU membership negotiations.

According to the Catalogue, waste is categorised into 20 groups, in terms of the source and origin, and this Catalogue is the basis for all national and international obligations on waste reporting. The European Waste Catalogue was regulated by the EU Commission as early as 2001, with a decision to establish list of waste (2001/118/EC), the same list that is included in the official Waste Management Strategy for the Period 2010-2019. 


\section{Table 1. EU Waste Catalogue}

\begin{tabular}{|c|c|}
\hline Index no. & Origin and source of waste \\
\hline 1 & $\begin{array}{l}\text { Wastes resulting from exploration, mining, quarrying, physical and } \\
\text { chemical treatment of minerals }\end{array}$ \\
\hline 2 & $\begin{array}{l}\text { Wastes from agriculture, horticulture, aquaculture, forestry, hunting and } \\
\text { fishing, food preparation and processing }\end{array}$ \\
\hline 3 & $\begin{array}{l}\text { Wastes from wood processing and the production of panels and furniture, } \\
\text { pulp, paper and cardboard }\end{array}$ \\
\hline 4 & Wastes from the leather, fur and textile industries \\
\hline 5 & $\begin{array}{l}\text { Wastes from petroleum refining, natural gas purification and pyrolytic } \\
\text { treatment of coal }\end{array}$ \\
\hline 6 & Wastes from inorganic chemical processes \\
\hline 7 & Wastes from organic chemical processes \\
\hline 8 & $\begin{array}{l}\text { Wastes from the manufacture, formulation, supply and use (MFSU) of } \\
\text { coatings (paints, varnishes and vitreous enamels), adhesives, sealants and } \\
\text { printing inks }\end{array}$ \\
\hline 9 & Wastes from the photographic industry \\
\hline 10 & Wastes from thermal processes \\
\hline 11 & $\begin{array}{l}\text { Wastes from chemical surface treatment and coating of metals and other } \\
\text { materials; non-ferrous hydro-metallurgy }\end{array}$ \\
\hline 12 & $\begin{array}{l}\text { Wastes from shaping and physical and mechanical surface treatment of } \\
\text { metals and plastics }\end{array}$ \\
\hline 13 & Oil wastes and wastes of liquid fuels (except edible oils, 05 and 12) \\
\hline 14 & Waste organic solvents, refrigerants and propellants (except 07 and 08) \\
\hline 15 & $\begin{array}{l}\text { Waste packaging; absorbents, wiping cloths, filter materials and protective } \\
\text { clothing not otherwise specified }\end{array}$ \\
\hline 16 & Wastes not otherwise specified in the list \\
\hline 17 & $\begin{array}{l}\text { Construction and demolition wastes (including excavated soil from } \\
\text { contaminated sites) }\end{array}$ \\
\hline 18 & $\begin{array}{l}\text { Wastes from human or animal health care and/or related research (except } \\
\text { kitchen and restaurant wastes not arising from immediate health care) }\end{array}$ \\
\hline 19 & $\begin{array}{l}\text { Wastes from waste management facilities, off-site waste water treatment } \\
\text { plants and the preparation of water intended for human consumption and } \\
\text { water for industrial use }\end{array}$ \\
\hline 20 & $\begin{array}{l}\text { Municipal wastes (household waste and similar commercial, industrial and } \\
\text { institutional wastes) including separately collected fractions }\end{array}$ \\
\hline
\end{tabular}

\section{Source: 2001/118/EC}

The Catalogue systematises over 800 types of waste, which, as previously presented, is divided into 20 groups. Each group contains subgroups that are marked with four digits, and they include an adequate type of waste. 
Table 2. A schema of waste index numbers

\begin{tabular}{|c|c|c|l|}
\hline Group & Subgroup & Index no. & \multicolumn{1}{c|}{ Title } \\
\hline 08 & & & $\begin{array}{l}\text { Wastes from the manufacture, formulation, } \\
\text { supply and use of coatings, adhesives, sealants } \\
\text { and printing inks }\end{array}$ \\
\hline 08 & 03 & & $\begin{array}{l}\text { Waste from the manufacture, formulation, supply } \\
\text { and use of printing inks }\end{array}$ \\
\hline 08 & 03 & 08 & Liquid water-based waste containing ink \\
\hline 08 & 03 & $12^{*}$ & Waste ink containing hazardous materials \\
\hline 08 & 03 & 13 & $\begin{array}{l}\text { Waste ink that is different from the one in } 0803 \\
12\end{array}$ \\
\hline
\end{tabular}

Source: Redžić et al., 2010, p. 10

As a part of each subgroup, waste is further classified according to the adequate index numbers, represented in a six-digit code, thus, depending on its characteristics, each type of waste can be precisely categorised in this manner. In order to have an additional clear-cut boundary between hazardous and nonhazardous waste, the former is marked with an asterisk following the index number, as seen in Table 2.

\section{EU Waste Management Polices}

The EU waste management policies are clearly defined by the EU Thematic Strategy on the Prevention and Recycling of Waste, which has been adopted by the European Commission. The main objective of the Strategy deals with avoiding waste and using waste as resource, primarily for secondary raw materials and energy production. The entire cycle, starting with production, via consumption, and all to the product disposal must be subject to the requirements of the recycling process or the secondary use of raw materials. Primarily, it is important to institutionalise adequate legislation, followed by creating institutionalised space for the implementation of laws and regulations, which would result in facilitation of the recycling process, as well as achieving high standards in the area of environmental protection.

As stated in the Waste Management Strategy for the Period 2010-2019 (Official Gazette of RS no. 29/2010, p. 9) "The EU waste policy outlines the development of measures such as:

- Promotion of cleaner production,

- Removal of hazardous characteristics of waste through treatment,

- Setting technical standards limiting content of certain hazardous substances in products, 
- Promotion of waste re-use and recycling,

- Application of economic instruments,

- Analysis of product life cycle,

- Development of eco-label scheme.“

Environmental protection is based on the precautionary and prevention principle. Namely, practice shows that it is by far more acceptable to initially act preemptively in terms of environmental protection, since the expenses of the potential environmental remediation are incomparably higher. "There is an opportunity that public authorities use emergency abrogating in order to reasonable apply precautionary and prevention principle” (Drenovak-Ivanović, 2009, pp. 165168). In some cases public authorities can apply emergency abrogating in order to protect public interest that is guaranteed by a law, enabling on that way aplication of the precautionary and prevention principle. There is always a dilemma under which circumstances public authorities should use emergency abrogation to protect public interest and environment in this case. (Drenovak-Ivanović, 2014, pp. 136137).

In this respect, all EU directives in this area prescribe the strict application of these principles:

- "The prevention principle - provide for nature and natural resources conservation through reduction of waste creation,

- The precautionary principle - provide for reduction of waste impact to human health and environment, as well decrease of dangerous substances amounts in waste,

- The polluter pays principle - ensure that waste creators and environment polluters bear costs and responsibility for their actions,

- The vicinity principle - provide for the appropriate infrastructure through the establishment of integrated and adequate system and network of facilities for waste treatment and disposal based on the principle of vicinity and care for own waste" Waste Management Strategy for the Period 20102019 (Official Gazette of RS no. 29/2010:9).

The above mentioned EU Thematic Strategy on the Prevention and Recycling of Waste was adopted in 2005, with an intention of establishing global long-term objectives in the area of recycling and reusing waste, paving way to the creation of a society that would gradually reduce the quantities of created waste, while at the same time stresses the importance of its recycling. As the main objective the Thematic Strategy lists modernising the existing legal framework, reducing the quantity of created waste, reusing and recycling, with waste disposal only as the last resort (COM(2011) 13 final, p. 3).

The EU polices in the area of waste management are based on reducing the negative effects on the environment, caused by the resource exploitation. Avoiding 
waste creation and a continual affirmation of the recycling process should result in the reduction of the negative effects on the environment and create conditions for a sustainable economic development.

In order to have an adequate response to the high strategic requirements and objectives, a distinct instrumentarium has been developed for the sake of their realisation. It consists of seven key procedures, whose application should result in the final realisation of the strategy objectives:

- Implementation and enforcement of existing EU waste legislation,

- Simplification and Modernisation,

- Introducing life-cycle Waste Prevention,

- Waste Prevention,

- Improving the knowledge base,

- Development of recycling standards,

- Further elaboration of the EU recycling policy. (COM(2011) 13 final, pp. 3-6).

\subsection{EU Legislation in the Area of Waste Management}

The EU legislation in the area of waste management is largely based on the above mentioned Thematic Strategy on the Prevention and Recycling of Waste (COM(2005) 666 final), adopted by the European Commission. The EU legislation is much older and far more developed than its Serbian counterpart, hence, it represents an example to be followed in the future development of legislation in Serbia.

The EU legislation in this area is very complex, owing to the fact that beside the general laws and bylaws that regulate environmental protection and waste management, there is a plethora of laws and bylaws that regulate specific segments in this area. (EU Waste Legislation, retrieved from http://ec.europa.eu/environment/waste/legislation/index.htm) The segments in this area are considered to be specific waste streams, and specific Directives that regulate each of them:

- EU Battery Directive, 2006/66/EC,

- EU Landfill Directive, 1999/31/EU,

- EU Waste Framework Directive, 2008/98/EC,

- The Restrictions of Hazardous Substances Directive, 2011/65/EU,

- Waste Electrical and Electronic Equipment Directive, 2012/19/EU,

- End of Life Vehicles Directive, 2000/53/EC,

- The Mining Waste Directive, 2006/21/EC,

- EU Packaging and Packaging Waste Directive, 94/62/EC, 
- Council Directive on the on the Disposal of Polychlorinated Biphenyls and Polychlorinated Terphenyls (PCBs / PCTs), 96/59/EC,

- The Urban Waste Water Treatment Directive, 91/271/EEC,

- EU Regulation on Ship Recycling and Amending Regulation, 1257/2013/EU,

- Council Directive on the Waste From the Titanium Dioxide Industry, 78/176/EEC, 82/883/EEC, 92/112/EEC,

- EU Directive on Waste Oils, 75/439/EEC.

From the previously listed specific waste streams, it is clearly possible to recognise the complexity of EU regulations in this area. However, contrary to the complex legislation in the EU, its Serbian counterpart consists of only one law and a set of bylaws that makes it less developed and inadequate for their mutual comparison, hence, the focus will only be placed on the Serbian legislation.

\subsection{The Republic of Serbia National Legislation in the Area of Waste Management}

Environmental protection has become a more intensely regulated area since the seventh and eight decade of the $20^{\text {th }}$ century. This was the period when there was an initiative to regulate certain areas such as the protection of air, natural environment, and environmental noise protection. The first systemic law that regulated the basic environmental protection issues in an all-encompassing way was the 1991 Environmental Protection Act, based on the Swedish 1969 Environmental Protection Act (Drenovak-Ivanović, 2015, pp. 9-10). This law set the foundation for the passing of subsequent acts, becoming the tipping point in a more serious approach to regulating this area of state legislation.

Up until 2004, the above mentioned Environmental Protection Act had been in effect, when, due to the conceptual imperfections, it was purposefully replaced by a completely new law. The Law on Environmental Protection (Official Gazette of $R S$, no.135/2004) represented a new legal framework in the area of environmental protection that has been completed with the adoption of the Law on Waste Management (Official Gazette of RS, no. 36/2009), as well as 16 additional acts. (Drenovak-Ivanović, 2015, p. 10).

There had been no significant changes of the above mentioned acts until early 2016, when there was an all-encompassing reform of these acts for the purpose of adapting legislation to the European standards. Of course, a plethora of bylaws have been passed in order to additionally regulate this area, however, the focus here will be on the above mentioned acts and their most recent amendments and additions that were passed by the Serbian National Assembly in early 2016.

The European Commission pointed out the lack of regulation in the area of ecology and environmental protection as a major drawback in Serbia's EU 
accession process. For this reason, as well as the fact that environmental protection and integrated waste management currently produce enormous benefits for the society as a whole, the changes in the legislation were unavoidable. Following the positive experiences of the European countries, as well as the experiences in the implementation of legislation thus far, a team of experts recommended certain corrections.

The changes in the Law on Environmental Protection have been made by the Amendments on the Law on Environmental Protection. (Official Gazette of RS, no. 14/2016) The most notable amendment is related to the establishment of the socalled Green Fund. It represents a state-budget fund, established for an indefinite period of time, regulated by the budget system legislation, and controlled by the Ministry (Official Gazette of RS, no. 14/2016, article 22). In the previous formulation of the law, there existed an Environmental Protection Fund that managed the projects and financial mediation in the area of conservation, sustainable use, protection and improvement of the environment, as well as the area of energy efficiency and the use of renewable energy sources (Lilić \& DrenovakIvanović, 2014, p. 139). Owing to the fact that the above mentioned fund was canceled by the 2012 Law on the Termination of the Law on Environmental Protection Fund (Official Gazette of RS, no. 93/2012), the Green fund has taken its place.

Environmental protection is performed through the application of the polluter pays and the user pays principles, as well as the subsidiary responsibility principle. (Official Gazette of RS, no.14/2016, article 21) The sources of finance for the activities of the fund are supplied through the appropriation process in the budget of the Republic of Serbia, as well as donations, credits, and other sources of public financing. The Green fund assigns financial resources to its users with the purpose of environmental protection and improvement. The government prescribes the conditions the potential users have to fulfill, the evaluation of the requests for the distribution of funds, as well as the method of distribution. It is also necessary to form an adequate regulatory body that would follow, analyze and supervise the expenditure of funds (Official Gazette of RS, no.14/2016, article 23).

The use of the Fund's resources has been separately regulated by the article 90v of the Law on Environmental Protection, and for the incentives of:

- Protection, preservation and improvement of the quality of air, water, soil and forests, mitigation of climate chances and ozone layer protection,

- Rehabilitation of waste landfills, encouragement of reduction of waste creation, recycling and waste re-use,

- Incentives for cleaner production and application of best available techniques for operation of facilities, as well as adapting to the environmental protection requirements, 
- Technology and products which shall reduce burden and pollution of the environment,

- Biodiversity protection and preservation, providing for the injured, diseased, seized or confiscated specimens of wild flora and fauna, including active protective measures such as reintroduction, repopulation and habitat maintenance,

- Incentives for use of renewable energy sources and increased energy efficiency,

- Incentives for building environmental protection infrastructure, especially for noise protection, as well as the creation of noise control guidelines and action plans.

- Incentives for cleaner transport, and other.

The establishment of the Green fund will generate conditions for the accumulation of funds that would later be used for the remediation of pollution and preservation of a healthy environment. In this manner, through subsidies, the government could support the activity of business entities, focusing them towards projects with the primary objective of reducing pollution. The recycling industry belongs to this category, owing to the fact that the core activity from a purely financial standpoint is not very profitable, however, with the government subsidies and other kinds of incentives, it can become a sustainable business that provides enormous non-financial benefits for the society as a whole.

At the same time, this fund represents a form of security for all potential investors in the recycling industry and other industrial branches that provide similar benefits for the entire society. Serbia possesses an enormous base of raw materials for the development of the recycling industry, which presents a way to permanently solve the systemic problem of unemployment. The development of the recycling industry is in itself a very expensive process, therefore, without the help of the government, both in a financial and regulatory way, through the creation of legislation and institutions for its implementation, it is not possible to expect significant results. For this reason, the creation of the above mentioned fund is an important leap forward towards the fulfillment of that goal.

As a part of the set of environmental laws came the changes to the Law on Waste Management, by passing the Law on Amendments and Additions to the Law on Waste Management (Official Gazette of RS, no.14/2016). Since the Law on Waste Management was passed in 2009, this has been the first major change of the law since 2010.

The Law on Amendments and Additions to the Law on Waste Management has several important objectives:

- Precisely defining the terms such as waste, waste management facility, waste decontamination, landfill, waste preparation and reuse, waste 
creator, secondary raw materials, waste management and treatment are defined in a different manner, and other (Official Gazette of RS, no.14/2016, article 2).

- There is a separate definition of the terms such as by-product, as well as the end-of-waste criteria, defined by the new $8 \mathrm{a}, 8 \mathrm{~b}, 8 \mathrm{v}$ i $8 \mathrm{~g}$ articles in the Law on Waste Management.

- Waste reuse and further use.

- A further development of the system of reporting and the register in the area of waste management.

In the majority of cases, the above mentioned terms have already been present in the previous formulation of the Law, however, due to the change of circumstances, as well as the further adaptation to the EU regulations, they had to be more precisely defined, while some of the terms are completely new. The term Bio-waste has been replaced by the term biodegradable waste. The terms waste management center, decontamination, permit, mobile waste management facility, as well as waste management and treatment have only been more precisely defined by modifying the existing articles of the Law. The term recycling has also been more precisely defined, whereas the term waste reuse has been considerably expanded, so that beside the article 5 point 21 of the Law, now there is also a point 21a. Waste creator and secondary raw materials have been separately defined by the modified and completely new article 5 points 25, 25a, 29, 29a of the Law, thus creating a basis for a definition of the term by-product, as well as the end-of-waste criteria, which is a significant novelty.

The above mentioned additions to the Law that deal with the end-of-waste criteria are in complete accord with the EU Waste Framework Directive (2008/98/EC). Treating by-products as secondary raw materials is of the uttermost importance for the recycling industry, thus, metals, non-ferrous metals, plastic, glass and paper no longer have the waste status, whereas the manufacturing byproducts are no longer considered as industrial waste. In this manner, the EU countries, and, in the future, Serbia will reap the benefits and material gain from using this waste instead of its disposal, which used to be the case.

The reuse of secondary raw materials as basic raw materials instead of waste is in accord with the above mentioned EU Directive, which is not only proclaiming the environmental, but also considerable financial benefits for the society as a whole.

The system for reporting on waste management that has been established by the adoption of this Law became additionally perfected following these additions. The changes have been focused towards the increase in frequency of reports on waste movement and its recycling, as well as the application of modern informational technologies, while creating online registers and databases on waste that are currently accessible over the Internet at any period of time using the computer. 
From annual and monthly reports, there was a gradual change toward daily updates, which has become obligatory since 2015, thus ensuring a more adequate monitoring of waste movement. This will be discussed separately in the final part of this paper dealing with the implementation of waste management legislation.

\section{The Implementation of Waste Management Legislation in Serbia}

The EU legislation in the area of waste management is very complex. One of the tasks that Serbia has on its way towards the EU is to adapt its regulations in the greatest possible measure to the European, which also includes the area of waste management. Save for passing new laws, regulations and other bylaws, which is the easier part of the problem, it is also necessary to implement these acts in practice at the level of business entities that deal with this type of industry. The biggest issue lies in the fact that for the implementation of such complex legislation it is necessary to have strong institutions that would not only supervise the implementation, but also continuously educate the business entities, whose business core is the subject of these regulations.

If one takes a look at the accomplished results, Serbia is on the right course in terms of passing regulations, however, it is only one side of the coin, i.e. the beginning of the process. The biggest issue comes from implementing these regulations and the supervision that is performed by the line Ministry. For this reason, the focus of this paper's practical part will be the information system between the legislators on the one side, and the business subject that is included in the process of waste collecting, treatment and recycling, on the other. The information system needs to be structured in such a way to ensure an adequate feedback, i.e. the returned information from the business entities, in order to remove the perceived imperfections of the system, as well as to raise the entire waste management system to a higher level.

At the core of the information system in Serbia, there are documents about the movement of waste, which are accordingly formed at the source of the waste and that subsequently follow it all the way to the facility for its treatment, i.e. recycling. Basically, there are two types of documents on waste movement that are regulated by separate acts - the Rulebook on the Form of the Document on Waste Movement and the Instruction for its Completion (Official Gazette of RS, no.114/2013), as well as the Rulebook on the Form of the Document on Hazardous Waste Movement and the Instruction for its Completion (Official Gazette of RS, no.114/2013). Thus, there is:

- A document on waste movement and

- A document on hazardous waste movement. 
The forms are almost completely identical in form and content, hence, in further discussion there will be a simultaneous description of both documents. The main difference lies in the fact that the former deals exclusively with waste that does not contain hazardous substances, whereas the latter deals exclusively with the movement of hazardous waste, which requires a more complex procedure not only in terms of transport, but also its treatment. Both of these forms existed earlier - they were published in the Official Gazette of RS, no.72/09 - and they had been in effect until early 2014, when the above mentioned forms, regulated by completely new rulebooks, replaced them.

The form of the document on waste movement consists of four parts in total. In the first part, marked with the letter $A$, the information about the waste is submitted by the waste creator, i.e. the owner of the waste. The $B$ part deals with the basic information about the waste creator, i.e. waste owner, whereas the third part, marked with the letter $C$, contains information about the waste transporter. The final part contains the information on the waste receiver (Official Gazette of RS, no.114/2013, Form of the Document on Waste Movement).

The form of the document on waste movement is created in four identical copies, out of which, the first copy is retained by the waste owner, the second by the waste transporter, the third by the waste receiver. The fourth copy is returned to the waste owner/creator by the waste receiver, in the period of up to 10 days from the date of receiving the waste. The hazardous waste transport contains another important characteristic, presented in the fact that the transport vehicles, as well as their drivers, need to have adequate ADR licenses, with an additional obligation of reporting the exact route of moving the hazardous material to the line Ministry.

The information system of waste management in Serbia is regulated by the Rulebook on Daily Records and Annual Reports of Waste Containing Instruction for its Completion (Official Gazette of RS, no. 95/2010, no. 88/2015), in which are defined both the basic methods and the means of reporting, not only on a daily basis, but also on an annual basis. The core of reporting is represented by the documents whose aggregation on a daily basis results in the daily records on waste, whereas the aggregation of daily records results in the annual report on waste.

"The daily records on waste are also regulated by the above mentioned Rulebook and are kept in the following forms:

- DEO 1 form - Daily records on waste by the waste creator,

- DEO 2 form - Daily records on waste by the waste storage facility manager,

- DEO 3 form - Daily records on waste by the waste reuse facility operator,

- DEO 4 form - Daily records on waste by the waste by the waste exporter,

- DEO 5 form - Daily records on waste by the waste by the waste importer, 
- DEO 6 form - Daily records on waste by the waste collectors and other waste owners”. (Official Gazette of RS, no. 95/2010, no. 88/2015, article 2)

"The annual reports on waste are kept in the following forms:

- GIO 1 form - The annual report on waste by the waste creator,

- GIO 2 form - The annual report on waste by the operator at the landfill of waste,

- GIO 3 form - The annual report on waste by the operator of the facility for waste reuse,

- GIO 4 form - The annual report on waste by the waste exporter,

- GIO 5 form - The annual report on waste by the waste importer,

- GIO 6 form - The annual report on waste by the waste by the waste collectors and other waste owners,

- KOM 1 form - The annual report on municipal waste" (Official Gazette of $R S$, no. 95/2010, no. 88/2015, article 3).

The Rulebook was adopted as early as 2010, when it was passed along with other bylaws, in the period following the adoption of the Law on Waste Management. The early version of the Rulebook proposed five forms in total, both for daily records and for annual waste records, with the exception of the KOM 1 form that represents the annual report on municipal waste.

With the current Amendments and Additions to the Law on Waste Management, as well as the Law on Environmental Protection, came the conditions for the corrections of the above mentioned Rulebook. The changes consisted of regulating new documents both for daily and annual reporting on waste, with the introduction of the DEO 6 and GIO 6 forms. With the introduction of these new forms, the information submission system has also faced considerable changes. The conventional way of submitting information in paper form has been replaced by electronic document submission, using the special online information system at the line Ministry website, which is a significant improvement comparing to the system that was previously in use.

Depending on the role in the waste management chain of command, each business entity submits an adequate form, while it is required from them to have a daily update on the amount of purchased and processed quantities of waste. The templates of these forms are provided in the annexes of the Rulebook, and some of the basic information that the header of each daily record must contain are the following:

- The period of reporting (year, month, date) to which the specific data is related to,

- The index number from the Waste Catalogue.

- Document number on waste creation, 
- Waste title,

- Waste description,

- First and last name of the person responsible for keeping record on waste (Official Gazette of RS, no. 95/2010, no. 88/2015, annex 1).

In the following part of the report, depending on the type, whether it is about the creator, operator, exporter importer, collector or other waste owner, there is an input on the quantity of treated waste, reused waste, as well as the amount of waste in stock. The name of the facility and the number of the valid license for waste collecting and treatment provided by the line Ministry is also written in the form. The templates of all the daily records that are used in the daily reporting on waste are provided in the Rulebook annex number 1.

A specific novelty is the DEO 6 form that it is filled out electronically in its entirety using the special information system of the National Register of Pollution Sources (NRIZ). Namely, all business entities, be it the waste creator or other waste owner, are required to fill out this register, according to the regulations. In this manner, in a very modern and efficient way, there is a means of constant monitoring of the waste management area, so that the line Ministry has an insight into relevant data from the area. Business entities that are registered in the National Register of Pollution Sources are required to submit information on a daily basis using the special information system, not only on the waste creation and purchase, but also on its treatment and further sale. The central data register is updated in this manner with new information on a daily basis, so that simultaneously with the daily records using the DEO 6 form, an annual GIO 6 report is generated without the additional obligation on the business subjects to provide the report separately.

The NRIZ information system, as well as the DEO 6 and GIO 6 forms, became a part of the Rulebook during the late September 2015, when the Law on the Amendments and Additions to the Rulebook on Daily Records and Annual Reports of Waste Containing Instruction for its Completion was passed (Official Gazette of $R S$, no. 88/2015). In order to get the business entities acquainted with the new methodology of filling out the report, the information system currently allows the editing of the previously entered information, hence, in case of mistakes, it is possible to correct them. Combined with the process of continuous education by organising specialised seminars and workshops, this ensures the long-term progress in the reporting process on waste movement, as well as the gradual movement from conventional reports in paper form to exclusively electronic reports.

The annual report on waste is performed using a group of regulated GIO forms, six in total number, as well as one KOM form that deals with municipal waste. The analogy is completely identical to the group of forms dealing with the daily records on waste. In this case, the difference is that the annual reports are generated by aggregating the individual daily records for a particular period of reporting. In this way, the Ministry has a clear insight into the movement, processing, export and 
import of different types of waste that are regulated by the catalogue, therefore, it has access to relevant information at all times.

The templates of all annual reports are proved by the annex 2 of the above mentioned Rulebook and they include the following information:

In the header of the report there is information on:

- Identification information on the business entity that files the report,

- The year of reporting,

- Information about the person responsible, as well as the person responsible for the waste management,

- Information on the waste management license, date of issue and license validity.

In the main part, the following is written:

- Waste index number from the Catalogue;

- The quantity of waste that is;

o created or collected,

o treated or processed,

o exported or imported.

- The important characteristics of waste (the name of the list it belongs to);

- The type of process for reusing the waste.

The classification of the collected waste is subsequently done according to the characteristics and contents, so that, in the form, there is a separate indication about the percent of collected municipal waste that is biodegradable, and in which percentage it contains paper, cardboard, glass, PET plastic, different types of metal, rubber, etc.

On the one hand, in terms of adopting the laws and rulebooks, Serbia is on a good path to achieving the objectives that have been set by the EU, whereas, on the other hand, the implementation of certain regulations is creating considerable problems for business entities on a daily basis. All business entities have mastered the conventional paper-form reporting on waste, with some minor or major drawbacks. Following the adoption of the Law on Waste Management and the adequate Rulebooks in 2010, the documents on waste creation have been embraced primarily by the major business entities, that subsequently necessitated their distributors to do so, by actively including them in the entire system of reporting with all the DEO and GIO types of forms in paper format.

The most recent Amendments and Additions to the Rulebook on Daily Records and Annual Reports of Waste Containing Instruction for its Completion resulted in the fundamental changes to the means of informing, and set the foundation for future reports by introducing the electronic means of submitting information as the dominant approach. 
The biggest issues appeared with the submission of the latest DEO 6 and GIO 6 forms. The underlying imperfection of these forms lies in the fact that it does not allow the user to have an insight into the current status of in-stock waste quantities at all times, in order to compare that status with the user's bookkeeping records. Therefore, in case of mistakes, they are hard to be determined owing to the lack of information, even though there is an option of editing the submitted data, i.e., correcting the mistakes. When submitting information on waste acquisition or purchase, the user needs to manually input the company name and address, i.e. there is no option for the system to recognise the user by submitting the Taxpayer Identification Number or the Company Registration Number, which would significantly speed up the process. With every form submission, as a necessary field, there is the license number and name of the business entity the user is selling waste to. Hence, the NRIZ absolutely takes under no consideration the fact that certain objects, that have not been completely worn out, could be sold to a natural person, who is certainly not included into the license system. Furthermore, the DEO 6 does not recognise waste export as an option, therefore, when a business entity exports a certain quantity of waste, it needs to write in the report that it sold the waste to itself, since there is no possibility of submitting the registration number of a foreign business entity that actually purchased the waste.

The most important practical fault is the inability to generate the types of GIO and DEO forms from 1 to 5, based on the GIO 6 and DEO 6 forms. In this way, all business entities that are liable to submit reports are required to simultaneously perform double reporting, both in paper and in electronic form, which not only increases the expenses but also provides opportunities for generating mistakes and discord in the reporting process.

There is, however, hope that the transition period from conventional to electronic means of informing will last as shortly as possible, as it is necessary to remove the above mentioned imperfections as soon as possible and additionally work on the improvement of the waste reporting system.

\section{Conclusion}

The issue of collecting, storing, and passing off waste into adequate streams represents an ever-growing issue of the contemporary society, and it requires a systemic approach in its resolving. In order to make an efficient and sustainable system, that includes the product creation, use, and, finally, storage and treatment, it is necessary to thoroughly regulate this area. The use of modern technology resulted in a true revolution of the manufacturing process, but simultaneously, it is necessary to develop a recycling industry not only for environmental, but also for economic reasons. 
Waste management has become quite a significant area, owing to the fact that in the past the priority used to be given to the quantitative component, i.e. the exclusively economic dimension of development which has been the primary and fundamental reason for the creation of the EU, whereas the qualitative characteristics of respecting ecological principles and sustainability were secondary. For this reason, countries that even in the slightest consider their future and the development of the manufacturing industry, simultaneously must develop the recycling industry, as it represents the precondition of its sustainability.

Waste management is a very complex area and it requires a multidisciplinary approach, not only in terms of passing regulations, but also in terms of their implementation. The EU countries have long ago realised the problem that the constantly created waste is causing to the modern society, so they have made a very decisive approach to solving this problem through the passing of adequate Directives and other bylaws. The network of regulations that is currently in effect in the EU is very complex and the Directives cover almost all areas where waste is potentially created. Through the implementation of concrete regulations using authorised legal institutions, the EU is using a very complex waste management system. Each Directive regulates its assigned area in a very precise way, which speaks in favour of a need for legislators to regulate these areas, as well as the significance of waste management itself.

On its way towards the EU, Serbia is obliged to adapt its legislation to the requirements of the member states. The waste management area is still at its early stages, owing to the fact that the above mentioned laws and bylaws only defined the issue of waste management in general terms. The intensification of the EU accession process has led to a literal transference and adoption of EU regulations without any consideration for the capabilities of the Serbian institutions for their implementation. This resulted in the lack of real effect of these laws, which in this alternate environment were unable to generate the desired effect and improve the regulation of the waste management area. The Serbian legislators should have additionally adapted every European law to the current state of institutions before passing these laws, in order to facilitate their transposition into the Serbian legal and constitutional order. Transposition of the ecology acquis into the Serbian legislation system requires increasing administrative capacity and maintaining it's stability by involving highly educated proffesionals in various different areas of environmental protection and climate change (Drenovak-Ivanović, 2016, pp.1112).

On a daily basis, a large number of business entities in the recycling industry are facing significant problems in the functioning and implementation of these laws. Partially, the problem lies in the business entities themselves, however, the biggest problem lies in the lack of a continuous education process, as well as the lack of significant financial support that the business community requires in this 
industrial branch. The recycling industry is a highly expensive industry and it requires considerable financial support from the government in order to further stimulate other business subjects to actively participate in the industry.

For this reason, many developed countries export enormous quantities of potential waste, because they are aware that their processing would require considerable funds. Serbia, along with other countries with a similar standard of living, is necessitated to import already used products, continue using them, and, eventually, hand them over to one of the recycling centers for further treatment.

Trough adequate projects, the EU offers these countries considerable grants that could be used to attract investments and fund this expensive process. The biggest issue in Serbia in this matter is generally a poor system of project creation and attracting investments, so that Serbia has been facing enormous penalties in the form of granted but not used funds. The problem lies primarily in the systemic organisation and not the lack of experts or competent staff.

The information system is one of the instruments of communication between the line Ministry and the business owners, and its improvement in any form goes in favour of raising the efficiency of waste management in Serbia. The informational technology is gradually being introduced and it is suppressing the conventional system of informing, therefore, in a much faster and efficient way, it provides an insight into the functioning of the entire system. Some of the bases have been set in the system, which leaves for the harder part of the work to further develop the system and make it more efficient, not only due to the requirements of the European Union but for the purpose of the environment and the society as a whole.

\section{References}

Commission of the European communities (2005), A Thematic Strategy on the prevention and recycling of waste $\operatorname{COM}(2005) 666$ final, Retrieved from: http://eurlex.europa.eu/legal-content/EN/TXT/PDF/?uri=CELEX:52005DC0666\&from=EN, accessed on May 10, 2016.

Drenovak-Ivanović, M. (2015), Ekološko zakonovstvo Srbije od prvog sistemskog zakona do primene standarda odgovornosti, Zaštita životne sredine u zakonodavstvu i praksi, str 9-14, Misija OEBS-a u Srbiji, Beograd, Retrieved from: http://www.osce.org/sr/serbia/148421?download=true , accessed on September 10, 2016.

Drenovak-Ivanović, M. (2009), Načelo predostrožnosti i vanredno ukidanje rešenja, Pravni kapacitet Srbije za evropske integracije 4/2009 (ur. S. Lilić), Pravni fakultet, Beograd.

Drenovak-Ivanović, M. (2016), Pregovori o pristupanju Srbije Evropskoj uniji-izazovi u poglavlju 27, Zbornik radova sa 12. konferencije Životna sredina ka Evropi, Beograd. 
Drenovak-Ivanović, M. (2014), Vanredno ukidanje rešenja: odnos javnog interesa i interesa zaštite životne sredine, Anali Pravnog fakulteta u Beogradu 2/2014, Beograd.

European Commision, (2001), List of wastes, Commission Decision 2001/118/EC, Retrieved from: http://eur-lex.europa.eu/LexUriServ/LexUriServ.do?uri= OJ:L:2001:047:0001:0031:EN:PDF , accessed on April 11,2016.

European commission, (2008) Waste Framework Directive 2008/98/EC, Retrieved from: http://eur-lex.europa.eu/LexUriServ/LexUriServ.do?uri= OJ:L:2008:312:0003:0030:en:PDF, accessed on April 25, 2016.

European commission, (2011), Report from the commission to the european parliament, the council, the european economic and social committee and the committee of the regions on the Thematic Strategy on the Prevention and Recycling of Waste, COM(2011) 13 final, Retrieved from: http://eurlex.europa.eu/LexUriServ/LexUriServ.do?uri=COM:2011:0013:FIN:EN:PDF, accessed on April 25, 2016.

European parliament and of the council, Decision No 1386/2013/EU, (2013), General Union Environment Action Programme to 2020 'Living well, within the limits of our planet, Official Journal of the European Union L354/171, Retrieved from: http://eurlex.europa.eu/LexUriServ/LexUriServ.do?uri=OJ:L:2013:354:0171:0200:EN:PDF, accessed on September 10, 2016.

Ivanjac, M. (1999), Pravni instrumenti politike zaštite životne sredine, zbornik radova Privreda i životna sredina - ekonomska i ekološka međuzavisnost, redaktor dr Božidar Milenović, Fakultet zaštite na radu, Niš.

Law on Amendments and Additions to the Law on Environmental Protection, (2016), “Official Gazette of RS”, no.14/2016.

Law on Amendments and Additions to the Law on Waste Management, (2016), "Official Gazette of RS”, no.14/2016.

Law on the Amendments and Additions to the Rulebook on Daily Records and Annual Reports of Waste Containing Instruction for its Completion, (2015), “Official Gazette of RS” no. 88/2015.

Law on Environmental Protection, (2004), “Official Gazette of RS”, no.135/2004.

Law on Waste Management, (2009), “Official Gazette of RS” no. 36/2009.

Law on the Termination of the Law on Environmental Protection Fund, (2012), "Official Gazette of RS”, no.93/2012.

Lilić, S., Drenovak-Ivanović, M. (2010), Ekološko pravo, Pravni fakultet, Beograd.

Lilić, S., Drenovak-Ivanović, M. (2014), Ekološko pravo, Pravni fakultet, Beograd.

Pajvančić, A.(2008), Ekološka svest kao univerzalna evropska vrednost, Evropska zajednica naroda i univerzalne vrednosti (zbornik međunarodnog naučnog skupa, NATEF), Novi Sad.

Redžić, N. Đorđević, Lj. Dukić, I. Misajlovski, N. Mihailović, L. (2010), Uputstvo za određivanje indeksnog broja, Agencija za zaštitu životne sredine, Beograd.

Rulebook on Daily Records and Annual Reports of Waste Containing Instruction for its Completion, (2010),“Official Gazette of RS”, no. 95/2010, 88/2015.

Rulebook on the Form of the Document on Hazardous Waste Movement and the Instruction for its Completion, (2013), “Official Gazette of RS”, no.114/2013.

Rulebook on the Form of the Document on Waste Movement and the Instruction for its Completion, (2013), “Official Gazette of RS”, no.114/2013. 
Vuksanović, V. (2001), Nadležnosto Evropske unije u oblasti zaštite životne sredine, Zaštita životne sredine u međunarodnom i unutrašnjem pravu- izbor najznačajnijih izvora prava, Ministarstvo zdravlja i zaštite životne okoline Republike Srbije, Uprava za zaštitu životne okoline, Beograd.

Waste Management Strategy for the Period 2010-2019, (2009), “Official Gazette of RS” no. 29/2010.

Zdravković, D., Radukić, S., (2006), Nacionalni sistem održivog razvoja i zaštite životne srdine u procesu pridruživanja Evropskoj uniji, Pelikan print, Niš. internet sajtovi :

EU waste legislation-Environment-European Commission: Retrieved from: http://ec.europa.eu/environment/waste/legislation/index.htm, accessed on April 15, 2017.

\section{KOMPARATIVNA ANALIZA SRPSKE I EVROPSKE ZAKONSKE REGULATIVE U OBLASTI UPRAVLJANJA OTPADOM}

Apstrakt: Upravljanje otpadom, ekološka svest i zaštita životne sredine bivaju sve aktuelnije teme početkom 21 . veka, a u prilog tome i govori činjenica da se sve veći broj autora bavi proučavanjem ekološkog prava i globalnim nivoom ekološke svesti u svetu. Savremeno potrošačko društvo se odlikuje kreiranjem velike količine raznih vrsta otpada. Cilj je kreirati savremen sistem integralnog upravljanja otpadom kako bi se ciklus proizvodnje i korišcenja zaokružio procesom reciklaže proizvoda na kraju korisnog veka upotrebe. Rad se bavi pregledom evropske i analizom srpske regulative u oblasti upravljanja otpadom. Evropsko zakonodavstvo u oblasti upravljanja otpadom je starije i daleko razvijenije $u$ odnosu na stepen regulative ove oblasti u Srbiji, tako da ono predstavlja osnovu za razvoj zakonske regulative kod nas. Aktuelna regulativa u Srbiji u oblasti upravljanja otpadom se u velikoj meri oslanja na regulativu u EU, ali je usled nedovoljno iskusnih i stabilnih institucija kod nas primena ovih propisa ispod očekivanog nivoa.

Ključne reči: Politika zaštite životne sredine, katalog otpada, upravljanje otpadom, reciklaža, zakonska regulativa, sistem izveštavanja o otpadu.

\section{Authors' biographies}

Mladen Krstić is born in Niš. He completed elementary and grammer school in Aleksinac. He graduated from the Faculty of Economics, University of Nis in 2010, and completed his Master's degree in Accounting, Auditing and Financial Management at the same University in 2012. Currently, he is a PhD student at the Faculty of Economics, University of Nis.

Tamara Milenković-Kerković is Full Professor at the Faculty of Economics, University of Niš and she teaches Commercial Law and International Trade Law at the undergraduate level of study and Banking Law and Competition 
Law at Masters and doctoral level of study as well. Her fields of specialisation include commercial conctracts, franchising law, payement protection law and consumer protection law. 